\title{
Hematological alterations during experimental canine infection by Trypanosoma cruzi
}

\author{
Alterações hematológicas durante a infecção canina experimental por Trypanosoma cruzi \\ Paulo Marcos Matta Guedes ${ }^{1}$; Vanja Maria Veloso, 5 ; Tiago Wilson Patriarca Mineo ${ }^{4}$; Juliana Santiago-Silva ${ }^{3}$; \\ Geovan Crepalde ${ }^{6}$; Ivo Santana Caldas ${ }^{6}$; Manuela Sales Lima Nascimento ${ }^{3}$; Marta Lana ${ }^{7}$; \\ Egler Chiari ${ }^{5}$; Lúcia Maria da Cunha Galvão ${ }^{2}$; Maria Terezinha Bahia ${ }^{6}$
}

\begin{abstract}
${ }^{1}$ Department of Microbiology and Parasitology, Health Science Center, Federal University of Rio Grande do Norte - UFRN, Rio Grande do Norte, RN, Brasil

${ }^{2}$ Health Science Center, Federal University of Rio Grande do Norte - UFRN, Rio Grande do Norte, RN, Brasil

${ }^{3}$ Department of Biochemistry and Immunology, University of São Paulo - USP, Ribeirão Preto, SP, Brasil

${ }^{4}$ Institute of Biomedical Sciences, Federal University of Uberlândia - UFU, Uberlândia, SP, Brasil

${ }^{5}$ Department of Parasitology, Biological Science Institute, Federal University of Minas Gerais - UFMG, Belo Horizonte, MG, Brasil

${ }^{6}$ Department of Biological Sciences, School of Pharmacy, Federal University of Ouro Preto - UFOP, Ouro Preto, MG, Brasil

${ }^{7}$ School of Pharmacy, Federal University of Ouro Preto - UFOP, Ouro Preto, MG, Brasil
\end{abstract}

Received June 20, 2011

Accepted September 21, 2011

\begin{abstract}
To confirm that Beagle dogs are a good experimental model for Chagas disease, we evaluated hematological alterations during the acute and chronic phases in Beagle dogs infected with the Y, Berenice-78 (Be-78) and ABC strains of Trypanosoma cruzi, correlating clinical signs with the parasitemia curve. We demonstrate that the acute phase of infection was marked by lethargy and loss of appetite. Simultaneously, we observed anemia, leukocytosis and lymphocytosis. Also,we describe hematological alterations and clinical signs that were positively correlated with the parasitemia during the experimental infection with the three strains of T. cruzi, and demonstrate that experimental infection of Beagle is a trustworthy model for Chagas disease.
\end{abstract}

Keywords: Trypanosoma cruzi, Beagle dogs, parasitemia, lymphocytosis, anemia, leukocytosis.

\section{Resumo}

Para confirmar que cães Beagle são um bom modelo para doença de Chagas, foram avaliadas as alteraçôes hematológicas durante as fases aguda e crônica em cáes Beagle infectados com as cepas Y, Berenice-78 (Be-78) e ABC de Trypanosoma cruzi, correlacionando os sinais clínicos com a curva de parasitemia. Foi demonstrado que a fase aguda da infecçáo foi marcada por letargia e perda de apetite. Simultaneamente, observou-se anemia, leucocitose e linfocitose. Ainda, foram descritas alteraçôes hematológicas e sinais clínicos positivamente correlacionados com a parasitemia durante a infecção experimental com as três cepas de T. cruzi estudadas, demonstrando que a infecção em cáes Beagle constitui um modelo fidedigno para a doença de Chagas.

Palavras-chave: Trypanosoma cruzi, cáes Beagle, parasitemia, linfocitose, anemia, leucocitose.

\section{Introduction}

One major stumbling block in research efforts to elucidate the mechanisms of pathogenesis of chronic Chagas disease is the lack of a suitable animal model. The murine model is frequently used because of its easy maintenance, low cost and diversity of

\footnotetext{
*Corresponding author: Paulo Marcos Matta Guedes

Department of Microbiology and Parasitology, Bioscience Center,

Federal University of Rio Grande do Norte - UFRN,

Av. Salgado Filho, s/n, CEP 59072-970, Natal, RN, Brazil

e-mail: pauloguedes@cb.ufrn.br
}

genetic lineages, as well as the availability of genetically deficient animals. However, the short half-life of this model interferes with reproduction of all the clinical forms of the disease. The canine model reproduces diffuse chronic myocarditis, as shown by electrocardiographic changes, along with cytokine, chemokine and antibody production with patterns similar to those found in humans (ANDRADE et al., 1981; ANSELMI et al., 1967; LANA et al., 1992; GUEDES et al., 2009; GUEDES et al., 2008; GUEDES et al., 2010). 
Chagas disease in humans induces anemia, thrombocytopenia and leukocytosis, mainly during the acute phase of disease (SHIKANAI-YASUDA et al., 1990). TNF- $\alpha$ can modulate myelopoiesis, erythropoiesis, lymphopoiesis and thrombocytopoiesis (ULICH et al., 1990). A study on mice reported that T. cruzi sheds trans-sialidase as a virulence factor that induces accelerated platelet depletion, thereby leading to hematological changes (TRIBULATTI et al., 2005). In fact, mice inoculated with different T. cruzi strains show intense thrombocytopenia, neutropenia, eosinophilia, anemia and leukocytosis during the acute phase of infection (MARCONDES et al., 2000). However, despite knowledge of the symptoms, no study has demonstrated the kinetics of hematological alterations occurring during acute and chronic Chagas disease. Hence, the aim of this study was to evaluate the hematological alterations during the acute and chronic phases, in Beagle dogs infected with T. cruzi strains that present distinct virulence patterns, and to correlate these results with parasitemia levels.

\section{Material and Methods}

In this study, we used three distinct strains (Y, Be-78 and ABC strains), which belong to Group II of $T$. cruzi strains (ZINGALES et al., 2009). These strains were chosen because Group II T. cruzi is the most prevalent form in Latin American patients. Moreover, the strains used were isolated from patients at different phases of the disease (acute and chronic) who presented different clinical manifestations (cardiac and digestive) or did not present symptoms.

Sixteen four-month-old Beagle dogs from the kennel of the Federal University of Ouro Preto (UFOP), Minas Gerais, Brazil, were used in this study. All the procedures and experimental protocols were approved by the Ethics Committee for Animal Research of UFOP. Twelve Beagles were inoculated intraperitoneally with $4.0 \times 10^{3}$ blood trypomastigotes $/ \mathrm{kg}$ of the $\mathrm{Y}, \mathrm{Be}-78$ or $\mathrm{ABC}$ strains of T. cruzi. Four age-matched uninfected dogs were used as controls. The parasitemia was monitored daily from the fifth day of infection until 50 days after infection, as described by Brener (1965).

The erythrocyte count, erythrocyte sedimentation rate, hematocrit level and leukocyte count were determined using standard methods (DACIE; LEWIS, 1984). For hematological analyses, blood samples were collected from the dogs before infection and 2, 4, 6, 8, 12, 50 and 100 weeks after infection.

Statistical analysis was performed using the Mann-Whitney or Kruskal-Wallis test, to make comparisons on two or three variables between the groups. Associations shown by parasitemia with hematocrit, leukocyte, erythrocyte and lymphocyte counts, erythrocyte sedimentation rate and hemoglobin levels were tested by using Spearman correlation and linear regression. Statistical significance between the groups was taken to be present with $\mathrm{p}<0.05$. All statistical analyses were done using GraphPad Prism version 5.0 (GraphPad Software Inc, La Jolla, CA, USA).

\section{Results}

Our results showed significant differences in the parasitemia curves of the dogs inoculated with the different T. cruzi strains (Y, Be-78 and $\mathrm{ABC}$ ), and that reductions in blood cell counts were closely correlated with parasitemia levels. The animals infected with the Y strain showed an earlier parasitemia peak (15 days) and significant reductions in erythrocyte and blood cell counts associated with higher erythrocyte sedimentation rates, two and four weeks post-infection (w.p.i.), compared with the uninfected animals (Figures 1a, 2b, c), at the same time points of the parasitemia peaks. In animals infected with Be-78 (parasitemia peak: 28 days), the reduction in blood cell counts was found to be most intense at 2, 4 and 6 w.p.i., as determined by the erythrocyte sedimentation rate (Figure 1a), and at 8 w.p.i., as displayed by the hematocrit level (Figure 1c). These animals showed a longer patent period than shown by the animals infected with the $\mathrm{Y}$ strain. The animals infected with $\mathrm{ABC}$ showed higher parasitemia levels and longer patent periods than shown by the dogs infected with $\mathrm{Y}$ and Be-78, and presented longer periods of reduced blood cell and erythrocyte counts (2 to 8 w.p.i.) (Figures 1a-c).

All the infected dogs showed enhanced leukocyte counts at 4 and 6 w.p.i. However, the animals infected with Y showed a reduced number of leukocytes at 8 w.p.i and the animals infected with $\mathrm{ABC}$ (parasitemia peak: 29 days) had higher leukocyte counts at 8 w.p.i. than shown by the uninfected animals (Figure 1d). Differential leukocyte counts were also determined.

We observed enhanced lymphocyte counts in all the groups of infected dogs at 2 and 4 w.p.i. Lymphocytosis was observed between 2 and 6 w.p.i. in 75\% of the animals infected with the $\mathrm{Y}$ and $\mathrm{ABC}$ strains, and $50 \%$ of the animals infected with Be-78 displayed lymphocytosis between 2 and 8 w.p.i. (Figure 1e). The monocyte counts of 50 and $25 \%$ of the animals infected with $\mathrm{ABC}$ and $\mathrm{Y}$ were higher than normal dog values. No significant alterations in eosinophil, basophil, plaque and bassinet levels were observed between the animals infected with different strains and the uninfected controls (data not shown).

The infected dogs presented anemia during the acute phase of T. cruzi infection, as assessed using red blood cell counts, hematocrit levels and hemoglobin content (Table 1). Beagle dogs inoculated with T. cruzi displayed correlations for anemia and leukocytosis with the parasitemia peaks, which were at 15 , 28 and 29 days for the $\mathrm{Y}, \mathrm{Be}-78$ and $\mathrm{ABC}$ strains, respectively. Anemia was observed in $50 \%$ of the animals infected with the $Y$ and $\mathrm{ABC}$ strains and $50 \%$ with Be-78. Leukocytosis was observed at the parasitemia peak ( 4 w.p.i.) in $25 \%$ of the dogs infected with Be-78 and ABC (Table 1).

Our results showed that the parasitemia peak was correlated with the erythrocyte count $(r=-0.645, \mathrm{p}=0.011)$ (Figure $2 \mathrm{a})$, hematocrit level $(r=-0.635, \mathrm{p}=0.015)$ (Figure $2 \mathrm{~b})$ and hemoglobin content $(r=-0.654, \mathrm{p}=0.010)$ (Figure $2 \mathrm{c})$, thus demonstrating that the parasitemia was also correlated with the anemia levels during the acute phase of infection. No correlations were observed between parasitemia and the erythrocyte sedimentation rate $(r=0.269$, $\mathrm{p}=0.198)$ (Figure $2 \mathrm{~d})$, leukocyte count $(r=0.054, \mathrm{p}=0.432)$ (Figure 2e) or lymphocyte count $(r=0.012, \mathrm{p}=0.358)$ (Figure 2f). 

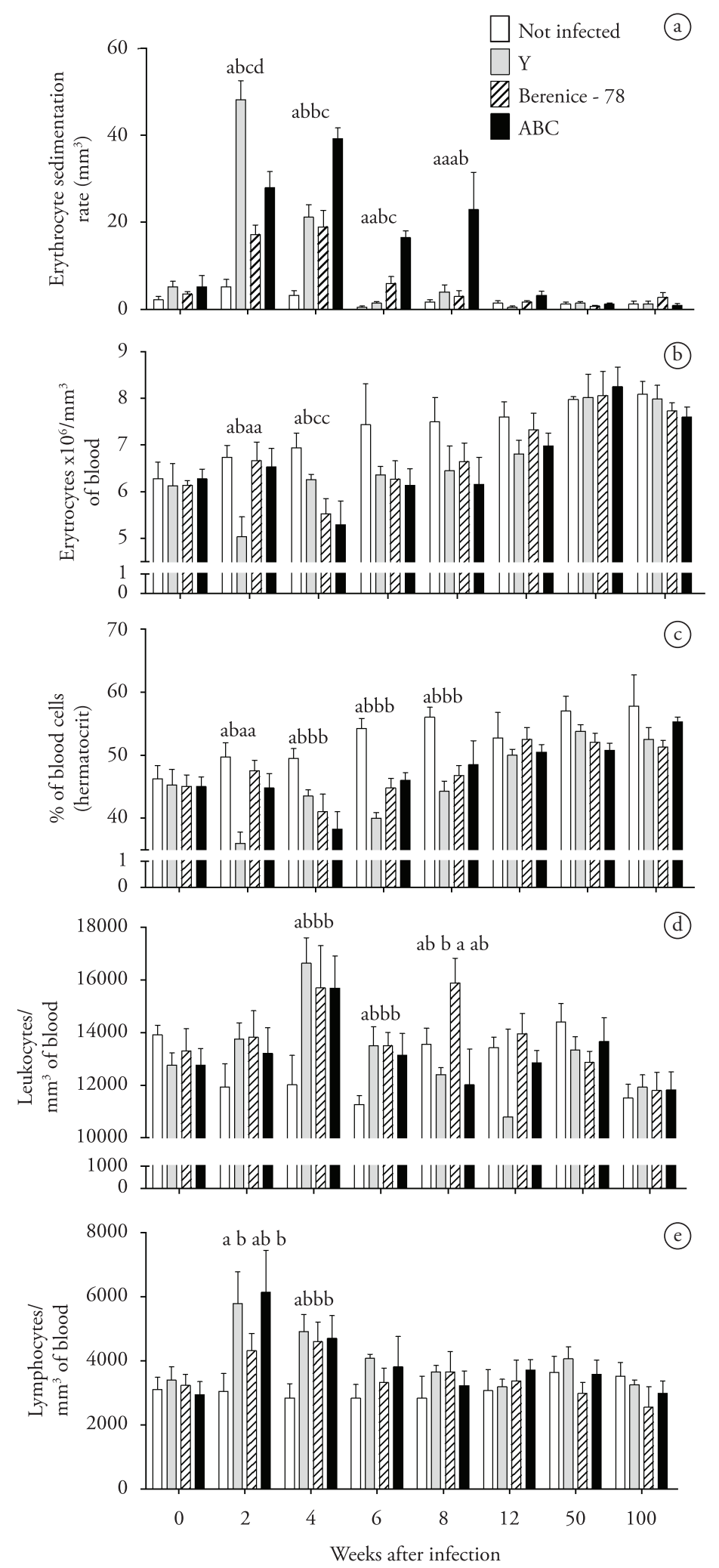

Figure 1. Erythrocyte sedimentation rate (a), erythrocyte count (b), hematocrit level (c), leukocyte count (d) and lymphocyte count (e) obtained from Beagle dogs inoculated with $4 \times 10^{3}$ blood trypomastigotes of the $\mathrm{Y}$, Berenice-78 and ABC strains of Trypanosoma cruzi. The results shown (mean \pm S.E.M.) represent one experiment (four animals per group). The statistical significance $(\mathrm{P}<0.05)$ is indicated as a, b, and $c$, such that different letters indicate statistical differences among the groups, and the same letters were used when no difference was observed. 
(a)
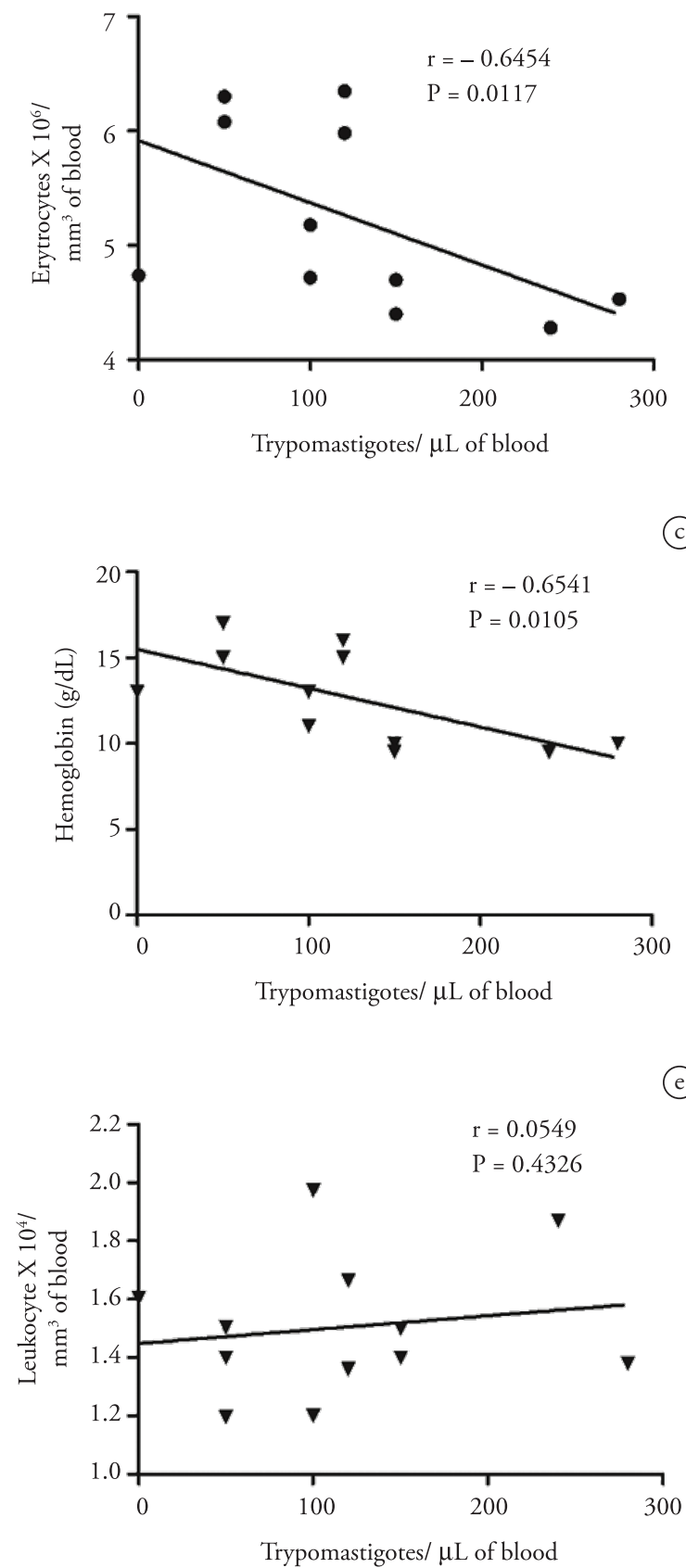

(b)

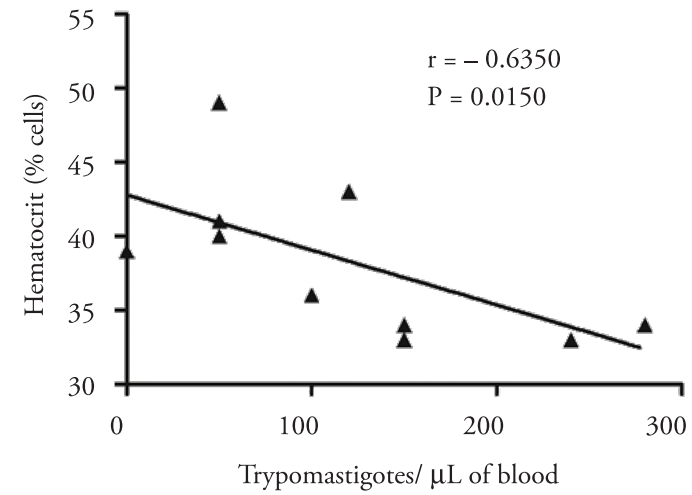

(d)

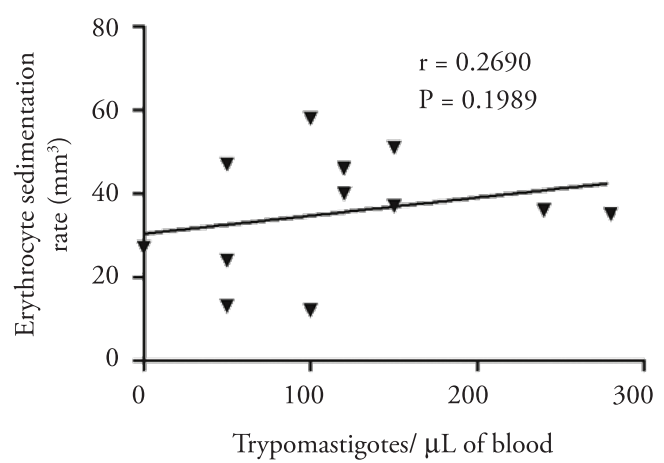

(f)

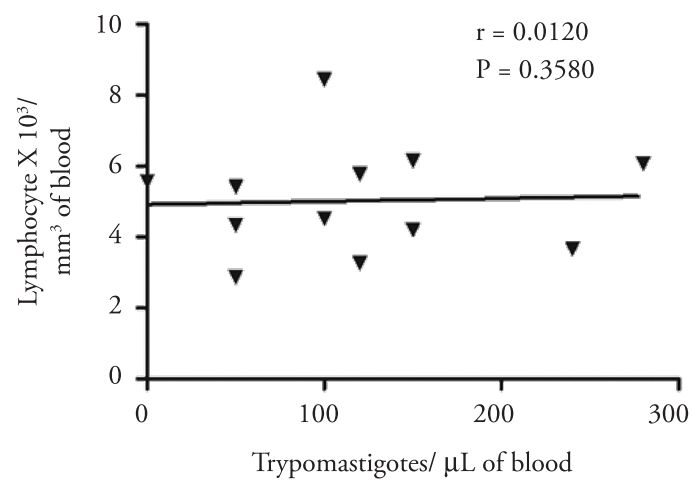

Figure 2. Correlations (Spearman's test) between the parasitemia peak and erythrocyte count (a), hemoglobin level (b), hematocrit level (c), erythrocyte sedimentation rate (d), leukocyte count (e) and lymphocyte count (f), over the same period, from Beagle dogs inoculated with $4 \times 10^{3}$ blood trypomastigotes of the Y, Berenice- 78 and ABC strains of Trypanosoma cruzi.

The hematological alterations and patent parasitemia observed during the acute phase of the experimental T. cruzi infection in Beagle dogs was also correlated with the clinical signs presented by the animals. The T. cruzi-infected animals showed elevated lethargy, enlargement of lymph nodes, appetite loss and fur loss between 2 and 6 w.p.i. These clinical signs were more pronounced in the animals infected with the $\mathrm{Y}$ and $\mathrm{ABC}$ strains, which presented higher parasitemia. These two groups of infected animals showed lower weight gains than seen among the uninfected control dogs (data not shown).

\section{Discussion}

Here, we demonstrated that high parasitemia levels were correlated with anemia during the acute phase of experimental T. cruzi infection in Beagle dogs, and that these animals displayed leukocytosis and lymphocytosis. Previously, using mongrel dogs, our group showed that the hemogram alterations were slight and inconsistent, without any correlation with infection (LANA et al., 1992). The lack of positive correlation observed previously may be explained by the heterogeneous genetic background. Data in 
Table 1. Blood cell counts in Trypanosoma cruzi-infected Beagle dogs.

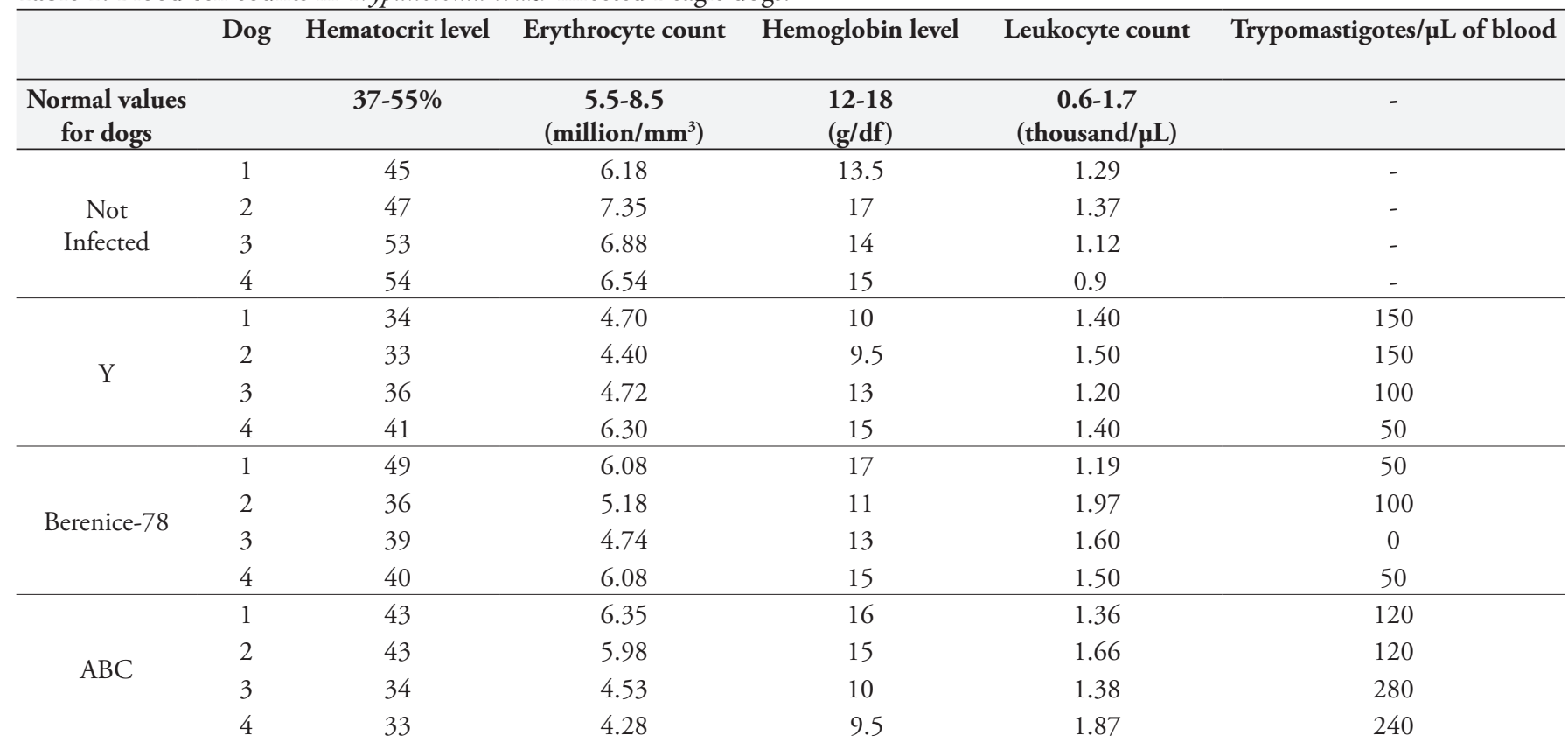

Beagle dogs were inoculated with $4 \times 10^{3}$ blood trypomastigotes of the $\mathrm{Y}$, Berenice- 78 and ABC strains of Trypanosoma cruzi, which generated parasitemia peaks in the dogs at 15, 28 and 29 days, respectively. This table shows the day of the parasitemia peak. The blood cell counts were performed 2 weeks after infection with the $Y$ strain, and 4 weeks after infection with the Berenice-78 and ABC strains. The normal values for dogs were obtained from Feldman [1].

the literature have shown that in the murine model, alterations in blood cell counts observed in the acute phase of T. cruzi infection are associated with bone marrow suppression of erythrocytes, megakaryocytes, granulocytes and macrophages; their precursors present impaired ability to fully mature (MARCONDES et al., 2000). Anemia was observed among the patients during the acute phase of T. cruzi infection, as also reported previously (DE TITTO; ARAUJO, 1988).

During the T. cruzi infective process, molecules produced by the parasite (e.g. trans-sialidase) or molecules derived from the immune response against the infection, like cytokines, chemokines, antibodies, nitric oxide or other inflammatory products, may also collaborate to produce alterations in hematological parameters (TRIBULATTI et al., 2005). High levels of TNF produced during the acute phase of experimental T. cruzi infection may interfere with myelopoiesis, erythropoiesis, lymphopoiesis and thrombocytopoiesis (ULICH et al., 1990). We demonstrated previously that dogs infected with the $\mathrm{ABC}, \mathrm{Be}-78$ and $\mathrm{Y}$ strains produce high levels of IFN- $\gamma$ and TNF (GUEDES et al., 2009). During the acute phase of Chagas disease, polyclonal activation of B and T lymphocytes has been observed (MINOPRIO et al., 1986), while in the present study we observed that infected dogs presented leukocytosis at 2 and 4 w.p.i. These findings are concordant with the literature: lymphocytosis has been described during the acute phase (14-17 days post-infection) of experimental T. cruzi infection with isolates obtained from opossums, armadillos or Beagle dogs (BARR et al., 1991).

Animals infected with different T. cruzi strains all showed increased lethargy, enlargement of lymph nodes, appetite loss and fur loss. Data in the literature have demonstrated that both naturally and experimentally infected dogs show clinical signs of Chagas disease, including cardiac hyperplasia, conduction disorders, lethargy, anorexia, ascites and respiratory difficulties (ANDRADE; ANDRADE, 1968; ANDRADE; ANDRADE, 1980; ANDRADE et al., 1984). The animals infected with the $\mathrm{Y}$ and $\mathrm{ABC}$ strains showed high parasitemia levels and all presented cardiomegaly, while the dogs infected with Be-78 showed low parasitemia levels and only 50\% displayed cardiomegaly (GUEDES et al., 2008). Dogs that showed cardiomegaly had higher rates of cardiac inflammation and fibrosis, and the development of chronic cardiomyopathy was correlated with high IFN- $\gamma$, TNF- $\alpha$, type- 1 chemokines and low IL-10 production (GUEDES et al., 2009, 2010).

We have previously shown that Beagle dogs are a good model for Chagas disease because they reproduce the clinical signs, parasitemia, immune responses and cardiac lesions (GUEDES et al., $2007,2008,2009,2010)$ in a manner that is very similar to what is observed in humans. Our findings indicate that the alterations in blood cell counts observed during the acute phase of experimental T. cruzi infection in Beagle dogs are associated with parasitemia levels and corroborate our previous reports. In conclusion, the data shown here demonstrate that the Beagle dog model is highly accurate in studies on the pathogenesis of Chagas disease.

\section{Acknowledgements}

This work was supported by the Research Support Foundation of the State of Minas Gerais (FAPEMIG), the National Research Council for Scientific and Technological Development (CNPq), and the Coordination Office for Advancement of University-level Personnel (CAPES). We also thank Lívia de Figueiredo, of the Chagas Disease Laboratory, Institute of Biological Sciences, UFOP, for animal care. 


\section{References}

Andrade SG, Andrade ZA. Pathology of prolonged experimental Chagas' disease. Rev Inst Med Trop São Paulo 1968; 10(3): 180-187. PMid:4982472.

Andrade ZA, Andrade SG. Pathology of experimental Chagas disease in dogs. Mem Inst Oswaldo Cruz 1980; 75(3-4): 77-95. http://dx.doi. org/10.1590/S0074-02761980000200008

Andrade ZA, Andrade SG, Sadigursky M. Damage and healing in the conducting tissue of the heart (an experimental study in dogs infected with Trypanosoma cruzi). J Pathol 1984; 143(2): 93-101. PMid:6737121. http://dx.doi.org/10.1002/path.1711430204

Andrade ZA, Andrade SG, Sadigursky M, Maguire JH. Experimental Chagas' disease in dogs. A pathologic and ECG study of the chronic indeterminate phase of the infection. Arch Pathol Lab Med 1981; 105(5): 460-464. PMid:6791609.

Anselmi A, Gurdiel O, Suarez JA, Anselmi G. Disturbances in the A-V conduction system in Chagas' myocarditis in the dog. Circ Res 1967; 20(1): 56-64. PMid:4959752.

Barr SC, Gossett KA, Klei TR. Clinical, clinicopathologic, and parasitologic observations of trypanosomiasis in dogs infected with North American Trypanosoma cruzi isolates. Am J Vet Res 1991; 52(6): 954-960. PMid:1909105.

Brener Z. Comparative studies of different strains of Trypanosoma cruzi. Ann Trop Med Parasitol 1965; 59: 19-26 PMid:14297351.

Dacie JV, Lewis SM. Clinical hematology. Practical Haematology. 6th ed. New York: Churchill Livingstone; 1984. p. 146-151.

De Titto EH, Araujo FG. Serum neuraminidase activity and hematological alterations in acute human Chagas' disease. Clin Immunol Immunopathol 1988; 46(1): 157-161. http://dx.doi. org/10.1016/0090-1229(88)90016-5

Guedes PMM, Veloso VM, Caliari MV, Carneiro CM, Souza SM, De Lana M, et al. Trypanosoma cruzi high infectivity in vitro is related to cardiac lesions during long-term infection in Beagle dogs. Mem Inst Oswaldo Cruz 2007; 102(2): 141-147. http://dx.doi.org/10.1590/ S0074-02762007005000003

Guedes PMM, Veloso VM, Gollob KJ, Afonso LCC, Caldas IS, Vianna $\mathrm{P}$, et al. IgG isotype profile is correlated with cardiomegaly in Beagle dogs infected with distinct Trypanosoma cruzi strains. Vet Immunol Immunopathol 2008; 124(1-2): 163-168. PMid:18439688. http://dx.doi. org/10.1016/j.vetimm.2008.03.003
Guedes PMM, Veloso VM, Talvani A, Diniz LF, Caldas IS, Do-Valle-Matta MA, et al. Increased type 1 chemokine expression in experimental Chagas disease correlates with cardiac pathology in Beagle dogs. Vet Immunol Immunopathol 2010; 138(1-2): 106-113. PMid:20619467. http://dx.doi. org/10.1016/j.vetimm.2010.06.010

Guedes PMM, Veloso VM, Afonso LC, Caliari MV, Carneiro CM, Diniz LF, et al. Development of chronic cardiomyopathy in canine Chagas disease correlates with high IFN-gamma, TNF-alpha, and low IL-10 production during the acute infection phase. Vet Immunol Immunopathol 2009; 130(1-2): 43-52. PMid:19211152. http://dx.doi. org/10.1016/j.vetimm.2009.01.004

Lana M, Chiari E, Tafuri WL. Experimental Chagas' disease in dogs. Mem Inst Oswaldo Cruz 1992; 87(1): 59-71. http://dx.doi.org/10.1590/ S0074-02761992000100011

Marcondes MC, Borelli P, Yoshida N, Russo M. Acute Trypanosoma cruzi infection is associated with anemia, thrombocytopenia, leukopenia, and bone marrow hypoplasia: reversal by nifurtimox treatment. Microbes Infect 2000; 2(4): 347-352. http://dx.doi.org/10.1016/ S1286-4579(00)00333-6

Minoprio PM, Eisen H, Forni L, D’Imperio Lima MR, Joskowicz M, Coutinho A. Polyclonal lymphocyte responses to murine Trypanosoma cruzi infection. I. Quantitation of both T- and B-cell responses. Scand J Immunol 1986; 24: 661-668. PMid:3099379. http://dx.doi. org/10.1111/j.1365-3083.1986.tb02185.x

Shikanai-Yasuda MA, Lopes MH, Tolezano JE, Umezawa E, Amato Neto V, Barreto AC, et al. Doença de Chagas aguda: vias de transmissão, aspectos clínicos e resposta à terapêutica específica em casos diagnosticados em um centro urbano. Rev Inst Med Trop São Paulo 1990; 32(1): 16-27. http://dx.doi.org/10.1590/S0036-46651990000100004

Tribulatti MV, Mucci J, Van Rooijen N, Leguizamón MS, Campetella $\mathrm{O}$. The trans-sialidase from Trypanosoma cruzi induces thrombocytopenia during acute Chagas' disease by reducing the platelet sialic acid contents. Infect Immun 2005; 73(1): 201-207. PMid:15618155 PMCid:538983. http://dx.doi.org/10.1128/IAI.73.1.201-207.2005

Ulich TR, Del Castillo J, Yin S. Tumor necrosis factor exerts dose-dependent effects on erythropoiesis and myelopoiesis in vivo. Exp Hematol 1990; 18(4): 311-315. PMid:2323367.

Zingales B, Andrade SG, Briones MRS, Campbell DA, Chiari E, Fernandes $\mathrm{O}$, et al. A new consensus for Trypanosoma cruzi intraspecific nomenclature: second revision meeting recommends TcI to TcVI. Mem Inst Oswaldo Cruz 2009; 104(7): 1051-1054. http://dx.doi.org/10.1590/ S0074-02762009000700021 